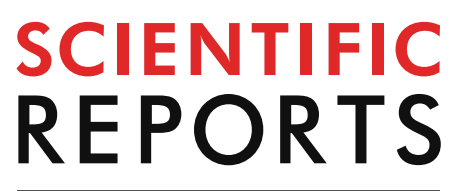

natureresearch

Check for updates

\title{
In-vitro propagation, callus culture and bioactive lignan production in Phyllanthus tenellus Roxb: a new source of phyllanthin, hypophyllanthin and phyltetralin
}

\author{
Harichandra A. Nikule ${ }^{1,2}$, Kirti M. Nitnaware $\mathbb{1}^{3}$, Mahadev R. Chambhare ${ }^{1}$,
} Nitin S. Kadam ${ }^{1,4}$, Mahesh Y. Borde ${ }^{1} \&$ Tukaram D. Nikam ${ }^{1 凶}$

This is the first report on identification and quantification of important hepatoprotective and anticancer polyphenolic lignans such as phyllanthin (PH), hypophyllanthin (HPH), niranthin (NH) and phyltetralin (PT) in natural plant and in vitro cultures of Phyllanthus tenellus Roxb. The identification of lignans was carried out by Liquid Chromatography-High Resolution Mass Spectrometry (LCHRMS) and quantified using High-Performance Liquid Chromatography (HPLC). In addition, an efficient protocol has been developed for multiple shoot induction in nodal explants of in vitro derived shoots of $P$. tenellus. Maximum number of shoot regeneration $(7.83 \pm 0.15)$ was achieved on medium incorporated with $1.0 \mathrm{mg} / \mathrm{l}$ 6-Benzylaminopurine (BAP). The medium containing Indole-3acetic acid (IAA) $2 \mathrm{mg} / \mathrm{l}$ was superior for induction of rooting in in vitro raised shoots. The plantlets were acclimatized to the field condition with $100 \%$ survival. The quantitative HPLC analysis showed that the lignan content was variable with the auxins and cytokinins incorporated in the medium. The lignan content was higher in callus grown on Murashige and Skoog (MS) medium + $2.0 \mathrm{mg} / \mathrm{l}$ Naphthaleneacetic acid (NAA). The reported protocol can be used for mass propagation and application of biotechnological approaches for improvement of $P$. tenellus. The results indicate intriguing possibilities for the utilization of $P$. tenellus plant parts as an alternative source and of callus culture to scale up bioactive lignan production for pharmaceutical applications.

Phyllanthus tenellus Roxb. (Long-stalk Phyllanthus, family- Phylanthaceae) is an annual, multipurpose medicinal herb. It has been used traditionally for urolithiasis in some part of the world, and therefore is also referred to as a stone breaker ${ }^{1}$. The herb has immunomodulatory, analgesic, anti-inflammatory, antimicrobial, antifungal, anti-hepatitis, antidiabetic and antitumor activity ${ }^{1-3}$. In addition, the plant extract is effective for curing the kidney, urinary bladder and intestinal disorders ${ }^{4,5}$. The phytochemical analysis showed the presence of medicinally important metabolites, such as niranthin, nirtetralin, hinoquinine and geranin ${ }^{6-8}$. Niranthin is highly effective as anti- hepatitis B surface antigen ${ }^{7}$. While nirtetralin and nirtetralin A, B effectively suppressed the secretion of the HBV (Hepatitis B virus); geraniin showed greater antioxidant and antihyperglycemic activities and niranthin has antiviral and anticancer activity ${ }^{7,9}$. Phyllanthin and hypophyllanthin are the most important bioactive lignans found in Phyllanthus species. Numerous studies have proved that phyllanthin and hypophyllanthin have cardioprotective, antihepatitis, antiviral, antifibrotic, anti-inflammatory, immunomodulatory, nephroprotective and anticancer activity ${ }^{10,11}$. To the best of our acquaintance, this is the first report on detection of medicinally important phyllanthin, hypophyllanthin and phyltetralin in P. tenellus.

\footnotetext{
${ }^{1}$ Department of Botany, Savitribai Phule Pune University, Pune 411007 , India. ${ }^{2}$ Central Instrumentation Facility, Savitribai Phule Pune University, Pune 411 007, India. ${ }^{3}$ Department of Botany, Hutatma Rajguru Mahavidyalaya, Rajgurunagar Dist., Pune 410 505, India. ${ }^{4}$ Design Innovation Centre, Department of Chemistry, Savitribai Phule Pune University, Pune 411 007, India. ${ }^{\circledR}$ email: tdnikam@unipune.ac.in; tdnikam37@gmail.com
} 
There are some reports available on in vitro propagation of different species of Phyllanthus such as $P$. urinaria, P. stipulatus and P. caroliniensis ${ }^{12-14}$. Despite having significant medicinal importance, Phyllanthus tenellus has so far received very meagre consideration on in vitro propagation and metabolite production ${ }^{15}$. Plant tissue culture has importance in propagation and production of secondary metabolites from plants that are economically and medicinally important and rare. This technique also delivers a significant approach for the enhanced production of plant metabolites by changing applications and combinations of growth regulators and application of elicitors in the culture media ${ }^{16,17}$.

Therefore, in the present study, attempts were made to develop an improved in vitro propagation protocol in $P$. tenellus. Study was also done to detect and test the ability of biosynthesis in biomass raised in plant tissue culture and natural environment for bioactive lignans phyllanthin, hypophyllanthin, niranthin and phyltetralin by using LC-HRMS and HPLC technique.

\section{Materials and methods \\ Establishment of in vitro shoot cultures. The six-week-old Phyllanthus tenellus Roxb. plants grown natu- rally in Botanical garden, Savitribai Phule Pune University, Pune, India (Latitude 18.554499, Longitude 73.825729) were used as a source of explants. The plant herbarium was submitted and authenticated at Botanical Survey of India, Western Circle. Pune, India (the specimen Voucher No. is BSI/WRC/Iden./2015/427, TDN-6). The nodal ( $1 \mathrm{~cm}$ in length with one node) and leaf explants $(3 \times 3 \mathrm{~mm}$ size) were washed six times with sterilized distilled water and disinfected by using $\mathrm{HgCl}_{2}(0.1 \% \mathrm{w} / \mathrm{v})$ for $3.5 \mathrm{~min}$. After washing with sterilized distilled water for six times, the fresh cut was applied at the exposed cut end of the explants. For establishment of shoot cultures, the explants were inoculated on medium ${ }^{18}$ containing BAP $(1 \mathrm{mg} / \mathrm{l})$. The explants were also inoculated on plant growth regulators free MS medium and treated as a control. The root, nodal and leaf explants excised from in vitro cultures were used in experiments on shoot regeneration on medium containing BAP, 6-furfurylaminopurine (Kin), Thidi- azuron (TDZ), IAA, Indole-3-butyric acid (IBA), NAA and 2,4-Dichlorophenoxyacetic acid (2,4-D) alone or in combination. Using nodal explants from in vitro raised cultures, the maintenance of multiple shoot regeneration was carried out on media fortified with $1.0 \mathrm{mg} / \mathrm{l}$ of BAP. All the in vitro cultures were grown in culture room with arrangement of $8 \mathrm{~h}$ fluorescent light (about $40 \mu \mathrm{mol} \mathrm{m}^{-2} \mathrm{~s}^{-1}$ ) and $16 \mathrm{~h}$ dark period and $25 \pm 2{ }^{\circ} \mathrm{C}$ temperature.}

In vitro rooting and acclimatization. The individual shoots with one or two nodes were transferred for rooting on medium fortified with NAA and IAA $(0.0$ to $3.0 \mathrm{mg} / \mathrm{l})$. After removal of agar medium, well grown plantlets were transferred to pots consisting of mixture of garden soil and sand (3:1). Initially for two weeks every day in the morning and evening, water was applied to the plantlets and acclimatized under shade-net $(50 \%$ natural light cut). Then plantlets were transferred to field condition (Temperature in the range of $12^{\circ} \mathrm{C}$ to $38^{\circ} \mathrm{C}$ ).

Induction, proliferation and maintenance of callus. For callus induction and proliferation, the nodal and leaf explants from in vitro raised shoots were used. This experiment was carried out on a medium containing BAP, Kin, TDZ, 2, 4-D and NAA (00 to $2.0 \mathrm{mg} / \mathrm{l})$ separately and 2, 4-D (2.0 mg/l) or NAA (2.0 mg/l) together with BAP, Kin or TDZ ( 00 to $3 \mathrm{mg} / \mathrm{l})$. The callus was maintained by subculturing $300 \mathrm{mg}$ of healthy callus onto fresh callus proliferation media (MS $+2.0 \mathrm{mg} / \mathrm{l} \mathrm{NAA}$ and $\mathrm{MS}+2.0 \mathrm{mg} / \mathrm{l} 2,4-\mathrm{D})$ at an interval of four weeks (18 subcultures). The fresh weight of callus was determined after four weeks of growth. To obtain dry weights, the calli were dried at $60^{\circ} \mathrm{C}$ in a hot air oven until constant weight $(72 \mathrm{~h})$.

Extraction of lignans and standard sample preparation. The dried biomass obtained from different experiments were ground to powder using mortar and pestle. On some modification, the method elaborated by Nitnaware et al. ${ }^{19}$ was used for extraction. The sample powder $(0.5 \mathrm{~g})$ was suspended in acetone $(20 \mathrm{ml})$ and ultra-sonicated for $45 \mathrm{~min}$ at ambient conditions. Then the suspension was filtered through Whatmann filter paper No.1 and the residue was extracted again in acetone $(20 \mathrm{ml})$ three times. The filtrate was pooled together and evaporated using rotary evaporator at $56^{\circ} \mathrm{C}$. The resultant residue was liquefied in HPLC grade methanol. The mixtures were filtered through $0.22 \mu \mathrm{m}$ filter and used for HPLC and LC-HRMS analysis.

The standard lignan compounds $\mathrm{PH}, \mathrm{HPH}, \mathrm{NH}$ and PT were purchased from Genetix Biotech Asia Pvt. Ltd., New Delhi, India. The solution of standard compounds (1 mg in $1 \mathrm{ml}$ of HPLC grade methanol) was prepared separately. The individual solution and the mixture of a solution of the standard compounds were diluted to make levels of $0.2,0.4,0.6,0.8$ and $1.0 \mathrm{mg} / \mathrm{ml}$. Each solution was filtered through $0.22 \mu \mathrm{m}$ syringe filter and used for HPLC analysis.

The specificity of lignan compounds extracted from calli subjected to various treatments was determined by comparing the retention time $(R t)$ and molecular ions $(\mathrm{m} / \mathrm{z})$ with respective standard compounds after chromatographic separation. The quantity of lignans in the plant sample was determined from the linear regression equation of the standard calibration curve.

HPLC of standard compounds and extracts. The lignans $\mathrm{PH}, \mathrm{HPH}, \mathrm{NH}$, and PT were assayed by HPLC (Agilent 1260 Infinity II with Diode Array Detector). A BDS Hypersil $\mathrm{C}_{18}$ column $(250 \times 4.6 \mathrm{~mm})$ at $25^{\circ} \mathrm{C}$ was used for separation of compounds. HPLC parameters were applied by referring Murugaiyah and Chan method ${ }^{20}$ with some modifications. The chromatographic separation was carried out using flow rate of $0.5 \mathrm{ml} /$ min of acetonitrile: water (55:45, v/v) isocratic mobile phase for $45 \mathrm{~min} .10 \mu \mathrm{l}$ of sample volume was used for injection and the detector was operated at $254 \mathrm{~nm}$.

Liquid chromatography high performance mass spectrometry analysis. The sample analysis was carried out using Thermo Fisher Scientific LC system and Bruker made Impact HD mass spectrometer 

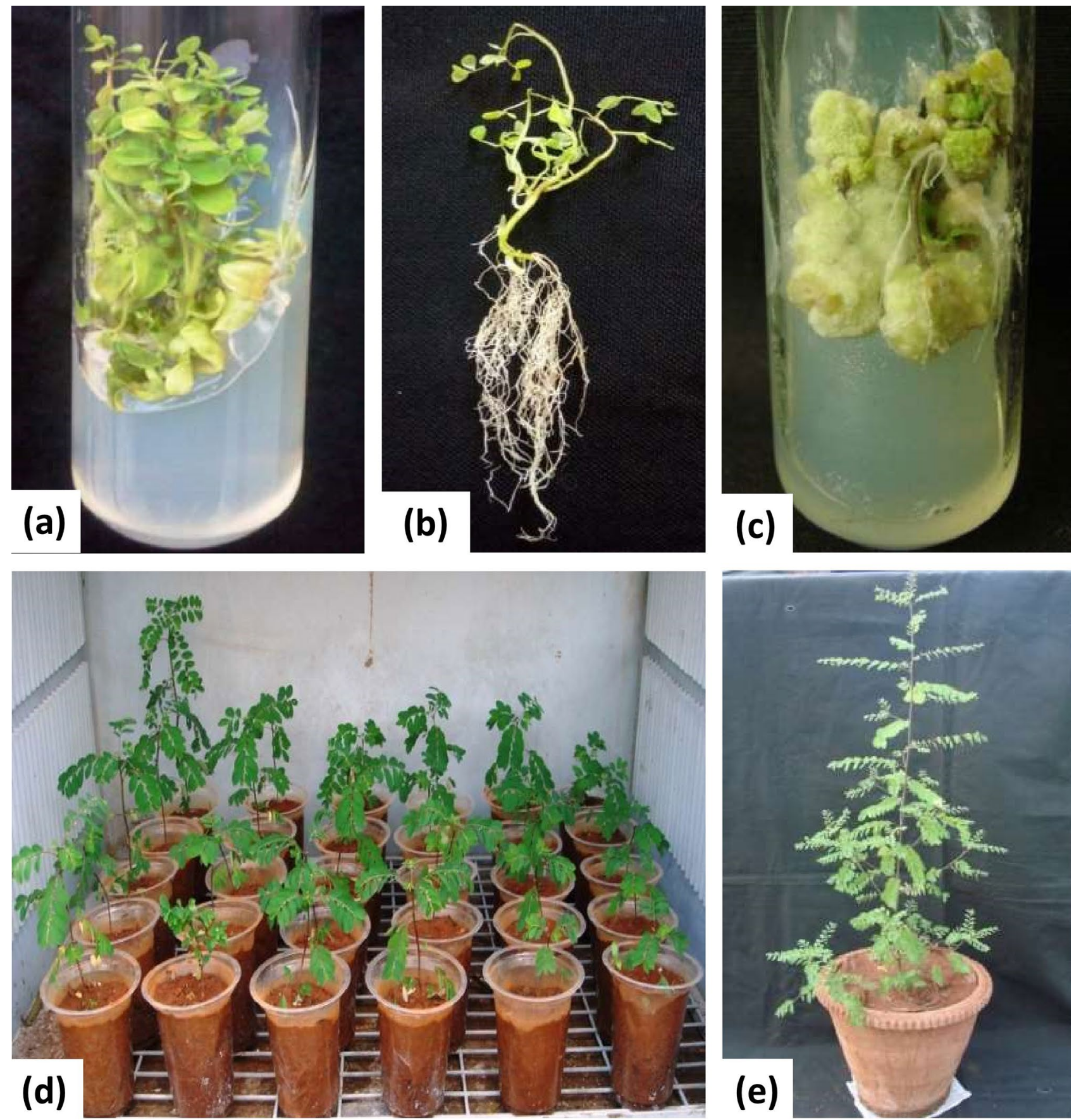

Figure 1. In vitro propagation of $P$. tenellus: (a) Multiple shoots formation in nodal explant on MS $+1 \mathrm{mg} / \mathrm{l}$ BAP, (b) Root formation in nodal explant on MS $+2 \mathrm{mg} / \mathrm{l} \mathrm{IAA,} \mathrm{(c)} \mathrm{Callus} \mathrm{induction} \mathrm{and} \mathrm{proliferation} \mathrm{in} \mathrm{leaf}$ explant on MS $+2 \mathrm{mg} / \mathrm{l}$ 2, 4-D, (d) Hardened plantlets after 15 days, and (e) Well acclimatized plantlets after six months.

interfaced with electrospray ionization (ESI) and time-of-flight (TOF). The $\mathrm{C}_{8}$ column (Dionex Bonded Silica, $250 \mathrm{~mm} \times 4.6 \mathrm{~mm}, 5 \mu \mathrm{m}$ ) was used for separation at $25^{\circ} \mathrm{C}$. The acidification of water and acetonitrile was carried out by adding formic acid $(0.1 \% \mathrm{v} / \mathrm{v})$. The acidified mobile phase of water and acetonitrile in a ratio of 40:60 (v/v) was used in isocratic mode. The volume of $15 \mu \mathrm{l}$ sample and standard mixture was injected separately. The flow rate was set at $0.7 \mathrm{ml} / \mathrm{min}$ for $35 \mathrm{~min}$. The detection of components of mixture was carried out using diode array detector at 190-400 $\mathrm{nm}$. The positive ESI mode of mass spectrometer was used for ionization. Nitrogen gas was used as nebulizing and drying gas at the flow rate of $71 / \mathrm{min}$. The spectra were documented in the mass range of $\mathrm{m} / \mathrm{z} 50-1,200$. The system capillary parameters were adjusted to temperature $200^{\circ} \mathrm{C}$, nebulizer pressure at 1.7 bars, capillary voltage (VCap) 4,500 V, and charging voltages $2000 \mathrm{~V}$. The instrument was controlled through software like chromeleon for LC, otofcontrol (3.4 version) for MS and Hystar was used for LC-MS. The exact mass of the molecular ions were assigned through Compass Data Analysis software (Version 4.2, Bruker, USA). 


\begin{tabular}{|c|c|c|c|c|c|c|}
\hline \multirow[b]{3}{*}{ PGRs } & \multirow[b]{3}{*}{ Conc. $(\mathrm{mg} / \mathrm{l})$} & \multicolumn{5}{|l|}{ Explants } \\
\hline & & \multicolumn{4}{|l|}{ Node } & \multirow[b]{2}{*}{ Leaf } \\
\hline & & $\begin{array}{l}\text { Explants responding for } \\
\text { shoot regeneration \% }\end{array}$ & No. of shoots \pm SE & Shoot length $\pm \mathrm{SE}$ (cm) & Morphological response & \\
\hline Control & 0.0 & $79.4 \pm 0.44^{\mathrm{i}}$ & $1.3 \pm 0.12^{j}$ & $2.3 \pm 0.12^{\mathrm{a}}$ & $\mathrm{R}, \mathrm{S}$ & $\mathrm{R}, \mathrm{S}$ \\
\hline \multirow[t]{4}{*}{ BAP } & 0.5 & $82.8 \pm 0.40^{\mathrm{h}}$ & $6.0 \pm 0.12^{\mathrm{b}}$ & $1.6 \pm 0.12^{\text {cde }}$ & $\mathrm{S}$ & $\mathrm{N}$ \\
\hline & 1 & $97.3 \pm 0.46^{\mathrm{a}}$ & $7.8 \pm 0.15^{\mathrm{a}}$ & $1.5 \pm 0.09^{\text {def }}$ & S & $\mathrm{N}$ \\
\hline & 2 & $91.2 \pm 0.60^{\mathrm{d}}$ & $4.5 \pm 0.20^{c}$ & $1.5 \pm 0.15^{\text {def }}$ & $\mathrm{S}^{*}$ & $\mathrm{~N}$ \\
\hline & 3 & $88.2 \pm 0.55^{\mathrm{fg}}$ & $3.3 \pm 0.15^{\mathrm{e}}$ & $1.0 \pm 0.15^{\mathrm{h}}$ & $\mathrm{S}^{*}$ & * \\
\hline \multirow[t]{4}{*}{ Kin } & 0.5 & $91.9 \pm 0.44^{\text {bcde }}$ & $1.6 \pm 0.06^{\mathrm{hi}}$ & $1.9 \pm 0.03^{\mathrm{b}}$ & $S$ & * \\
\hline & 1 & $93.3 \pm 0.65^{\text {bcde }}$ & $1.6 \pm 0.01^{\mathrm{hi}}$ & $1.8 \pm 0.09^{\mathrm{bc}}$ & $\mathrm{S}$ & * \\
\hline & 2 & $89.5 \pm 0.87^{\mathrm{ef}}$ & $1.7 \pm 0.01^{\mathrm{h}}$ & $1.7 \pm 0.06^{\text {cd }}$ & S & * \\
\hline & 3 & $85.8 \pm 1.47^{\mathrm{g}}$ & $1.6 \pm 0.01^{\mathrm{hi}}$ & $1.3 \pm 0.06^{\mathrm{fg}}$ & $\mathrm{S}^{*}$ & * \\
\hline \multirow[t]{4}{*}{ TDZ } & 0.5 & $77.2 \pm 0.61^{\mathrm{i}}$ & $1.1 \pm 0.03^{\mathrm{jk}}$ & $0.5 \pm 0.06^{\mathrm{ij}}$ & $\mathrm{S}^{*}$ & * \\
\hline & 1 & $77.2 \pm 0.60^{\mathrm{i}}$ & $1.0 \pm 0.06^{\mathrm{k}}$ & $0.4 \pm 0.03^{\mathrm{ijk}}$ & $\mathrm{S}^{*}$ & ** \\
\hline & 2 & $74.2 \pm 0.47^{j}$ & $1.0 \pm 0.00^{\mathrm{k}}$ & $0.3 \pm 0.01^{\mathrm{ijk}}$ & $\mathrm{S}^{*}$ & $* *$ \\
\hline & 3 & $71.1 \pm 0.61^{\mathrm{k}}$ & $0.9 \pm 0.00^{\mathrm{k}}$ & $0.2 \pm 0.00^{\mathrm{k}}$ & $S^{*}$ & $* *$ \\
\hline
\end{tabular}

Table 1. Effect of different concentrations of cytokinins on shoot regeneration in Phyllanthus tenellus Roxb. The value represents the means of three replicates with standard error (SE). Values sharing the different alphabets are statistically different from each other at $\mathrm{P}<0.05$. $R$ root, $S$ shoot, $N$ no change. ${ }^{\star}$ Callus induction. ${ }^{* *}$ Callus induction and proliferation.

\begin{tabular}{|c|c|c|c|c|c|c|c|}
\hline \multirow[b]{3}{*}{ PGRs } & \multirow[b]{3}{*}{ Conc. mg/l } & \multicolumn{6}{|l|}{ Explants } \\
\hline & & \multicolumn{3}{|l|}{ Node } & \multicolumn{3}{|l|}{ Leaf } \\
\hline & & Nature of callus & FW (g) & DW (mg) & Nature of callus & FW (g) & DW (mg) \\
\hline Control & 00 & $\mathrm{~N}$ & $\mathrm{~N}$ & $\mathrm{~N}$ & $\mathrm{~N}$ & $\mathrm{~N}$ & $\mathrm{~N}$ \\
\hline \multirow[t]{4}{*}{ NAA } & 0.5 & WGC & $0.73 \pm 0.6^{c}$ & $177.5 \pm 3.1^{c}$ & GWC & $1.16 \pm 0.3^{c}$ & $187.2 \pm 2.3^{c}$ \\
\hline & 1 & WGC & $1.12 \pm 1.1^{\mathrm{b}}$ & $201.4 \pm 1.4^{\mathrm{b}}$ & GWC & $1.81 \pm 0.8^{\mathrm{a}}$ & $232.6 \pm 2.7^{b}$ \\
\hline & 2 & WGC & $1.21 \pm 1.2^{\mathrm{a}}$ & $212.7 \pm 3.3^{\mathrm{a}}$ & GWC & $1.88 \pm 0.7^{b}$ & $237.2 \pm 1.8^{\mathrm{a}}$ \\
\hline & 3 & WGC & $1.22 \pm 1.3^{\mathrm{a}}$ & $204.8 \pm 2.3^{b}$ & GWC & $1.75 \pm 0.3^{b}$ & $228.6 \pm 1.9^{b}$ \\
\hline \multirow[t]{4}{*}{$\mathrm{NAA}+\mathrm{BAP}$} & 0.5 & GC & $1.20 \pm 1.1^{\mathrm{a}}$ & $205.2 \pm 1.3^{\mathrm{b}}$ & GC & $1.25 \pm 0.3^{\mathrm{b}}$ & $225.3 \pm 1.3^{\mathrm{a}}$ \\
\hline & 1 & GC & $1.00 \pm 0.6^{\mathrm{b}}$ & $195.6 \pm 0.3^{c}$ & GC & $1.21 \pm 0.6^{\mathrm{a}}$ & $218.2 \pm 1.1^{\mathrm{b}}$ \\
\hline & 2 & GC & $0.75 \pm 0.4^{c}$ & $181.8 \pm 0.8^{\mathrm{d}}$ & GC & $0.86 \pm 1.4^{\mathrm{c}}$ & $199.5 \pm 0.7^{\mathrm{c}}$ \\
\hline & 3 & GC & $0.71 \pm 0.3^{\mathrm{c}}$ & $175.3 \pm 0.7^{\mathrm{e}}$ & GC & $0.81 \pm 1.7^{\mathrm{c}}$ & $187.3 \pm 1.2^{\mathrm{d}}$ \\
\hline \multirow[t]{4}{*}{$\mathrm{NAA}+\mathrm{Kin}$} & 0.5 & GWF & $1.20 \pm 0.3^{\mathrm{a}}$ & $208.8 \pm 5.5^{\mathrm{a}}$ & GWF & $1.81 \pm 0.3^{\mathrm{c}}$ & $229.4 \pm 5.2^{\mathrm{a}}$ \\
\hline & 1 & GWF & $0.95 \pm 0.6^{\mathrm{b}}$ & $189.8 \pm 4.6^{\mathrm{b}}$ & GWF & $1.68 \pm 0.8^{\mathrm{a}}$ & $212.4 \pm 2.8^{\mathrm{b}}$ \\
\hline & 2 & GWF & $0.82 \pm 0.8^{c}$ & $173.6 \pm 4.1^{\mathrm{c}}$ & GWF & $1.42 \pm 0.7^{\mathrm{b}}$ & $201.6 \pm 4.3^{c}$ \\
\hline & 3 & GWF & $0.76 \pm 0.1^{\mathrm{d}}$ & $162.5 \pm 3.2^{\mathrm{d}}$ & GWF & $1.35 \pm 0.3^{\mathrm{b}}$ & $188.7 \pm 2.3^{\mathrm{d}}$ \\
\hline \multirow[t]{4}{*}{$\mathrm{NAA}+\mathrm{TDZ}$} & 0.5 & GC & $1.15 \pm 0.2^{c}$ & $201.4 \pm 1.1^{\mathrm{b}}$ & GF & $1.71 \pm 0.2^{\mathrm{d}}$ & $222.7 \pm 5.6^{\mathrm{b}}$ \\
\hline & 1 & GC & $1.12 \pm 0.3^{\mathrm{a}}$ & $183.3 \pm 2.8^{\mathrm{a}}$ & GF & $1.62 \pm 0.4^{\mathrm{c}}$ & $204.6 \pm 0.8^{\mathrm{a}}$ \\
\hline & 2 & GC & $1.00 \pm 0.4^{\mathrm{a}}$ & $163.7 \pm 1.4^{\mathrm{c}}$ & GF & $1.48 \pm 1.2^{\mathrm{a}}$ & $184.4 \pm 4.1^{\mathrm{c}}$ \\
\hline & 3 & GC & $0.92 \pm 0.2^{b}$ & $152.3 \pm 3.6^{\mathrm{d}}$ & GF & $1.23 \pm 1.2^{\mathrm{b}}$ & $161.3 \pm 4.2^{\mathrm{c}}$ \\
\hline
\end{tabular}

Table 2. Effect of different concentrations of NAA alone and in combination with cytokinins on growth of callus in Phyllanthus tenellus Roxb. The value represents the means of three replicates with standard error (SE). Values sharing the different alphabets are statistically different from each other at $\mathrm{P}<0.05$. $N$ no callus formation, WGC whitish green compact, GC green compact, GWF greenish white friable, GWC greenish white compact, GF green friable.

Statistical analysis. In the present study, experiments were performed in a completely randomized design with at least fourteen replicates. Each experiment was repeated at least thrice and data were recorded after 28 days of culture. The data was analyzed by one-way ANOVA using Duncan's Multiple Range Test ( $P \leq 0.5$ levels).

\section{Results and discussion}

Shoot induction and multiplication. It is understood that the, culture medium, source and age of explants, surface sterilization treatments, microbial contaminants and environmental factors are the critical factors for establishment of in vitro cultures. Literature survey reveals that the choice of explants and growth regulators is a fundamental requirement for any plant regeneration protocol ${ }^{21}$. In the current study, the pre- 


\begin{tabular}{|l|l|l|l|l|l|l|}
\hline \multirow{4}{*}{ Type of sample } & Lignans & $\begin{array}{l}\text { Retention time } \\
(\mathbf{m i n})\end{array}$ & $\begin{array}{l}\text { Molecular weight } \\
(\mathbf{g} / \mathbf{m o l})\end{array}$ & $\begin{array}{l}\text { Experimental } \\
\text { mass }(\mathbf{M}+\mathbf{N a}) \\
(\mathbf{m} / \mathbf{z})\end{array}$ & $\begin{array}{l}\text { Molecular } \\
\text { formula }\end{array}$ & Error (ppm) \\
\hline \multirow{5}{*}{ Standard } & Phyltetralin & 14.7 & 416.500 & 439.2002 & $\mathrm{C}_{24} \mathrm{H}_{32} \mathrm{O}_{6}$ & 20.30 \\
\cline { 2 - 7 } & Phyllanthin & 16.2 & 418.530 & 441.2164 & $\mathrm{C}_{24} \mathrm{H}_{34} \mathrm{O}_{6}$ & 19.10 \\
\cline { 2 - 7 } & Hypophyllanthin & 16.9 & 430.497 & 453.1798 & $\mathrm{C}_{24} \mathrm{H}_{30} \mathrm{O}_{7}$ & 18.90 \\
\cline { 2 - 7 } & Niranthin & 20.0 & 432.513 & 455.1953 & $\mathrm{C}_{24} \mathrm{H}_{32} \mathrm{O}_{7}$ & 19.10 \\
\hline \multirow{5}{*}{ P. tenellus extract } & Phyltetralin & 14.7 & 416.500 & 439.2007 & $\mathrm{C}_{24} \mathrm{H}_{32} \mathrm{O}_{6}$ & 19.10 \\
\cline { 2 - 7 } & Phyllanthin & 16.2 & 418.530 & 441.2167 & $\mathrm{C}_{24} \mathrm{H}_{34} \mathrm{O}_{6}$ & 18.20 \\
\cline { 2 - 7 } & Hypophyllanthin & 17.0 & 430.497 & 453.1811 & $\mathrm{C}_{24} \mathrm{H}_{30} \mathrm{O}_{7}$ & 16.00 \\
\cline { 2 - 7 } & Niranthin & 20.2 & 432.513 & 455.1968 & $\mathrm{C}_{24} \mathrm{H}_{32} \mathrm{O}_{7}$ & 15.80 \\
\hline
\end{tabular}

Table 3. Bioactive lignans detection and characterisation in P. tenellus by using LC-HRMS.
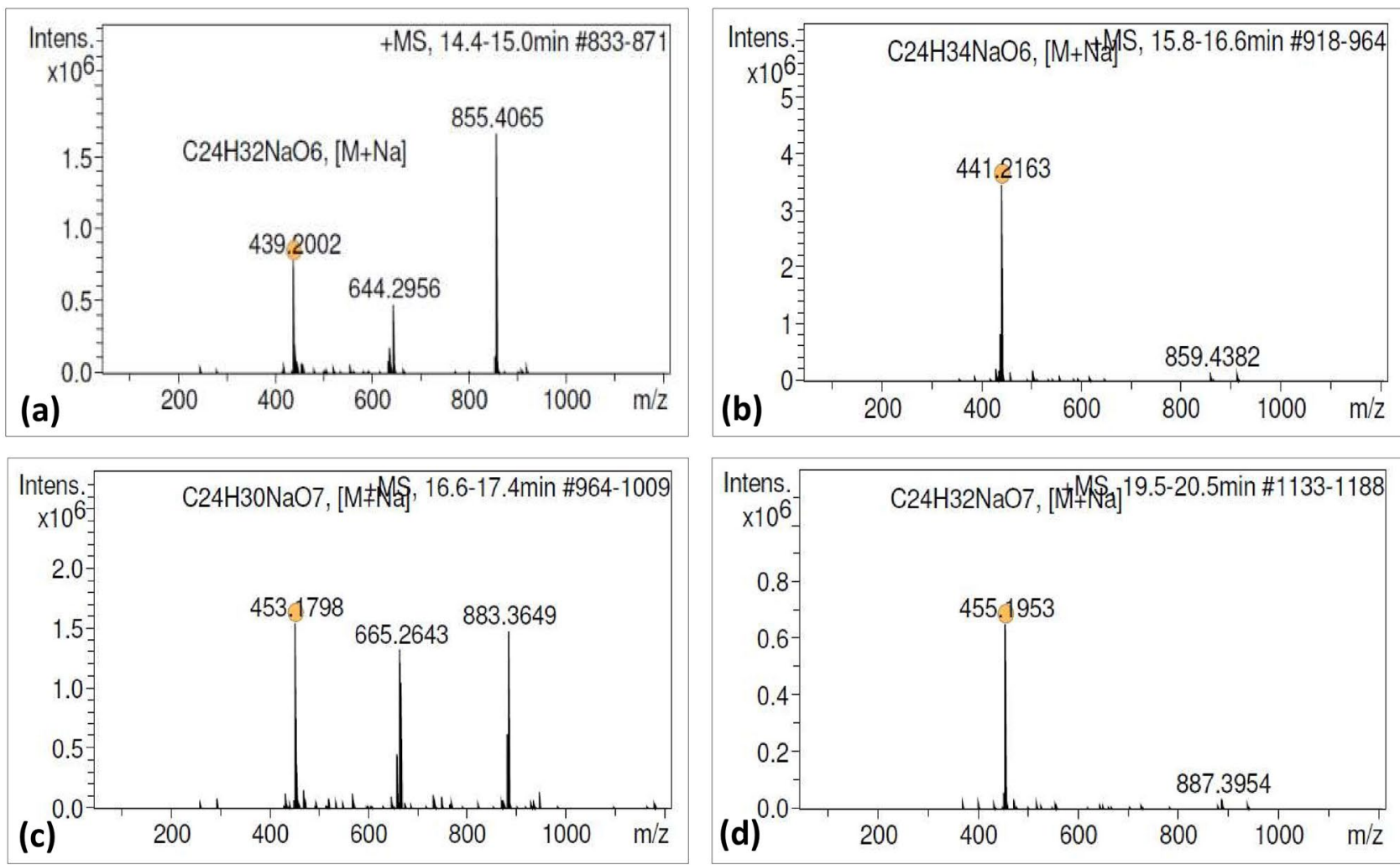

Figure 2. Product mass spectra of $[\mathrm{M}+\mathrm{Na}]$ positive ions of reference standards: (a) Phyltetralin (m/z 439.2002), (b) Phyllanthin (m/z 441.2163), (c) Hypophyllanthin (m/z 453.1798), and (d) Niranthin (m/z 455.1953).

liminary experiments were performed for establishment of in vitro shoot cultures using nodal and leaf explants obtained from field grown plants. The nodal explants (44\%) showed positive response by 1-2 shoot regeneration on medium containing $1.0 \mathrm{mg} / \mathrm{l} \mathrm{BAP}$. While remaining nodal explants and all leaf explants did not show any response for shoot regeneration. To prevent or to minimize the chances of somaclonal variation, nodal explants are most preferred, as pre-existing meristem permits multiple shoot formation without the intervention of callus formation $^{22}$. To optimize in vitro propagation protocol, in vitro regeneration of shoots from different parts of in vitro grown plantlets has received attention ${ }^{23,24}$. In the current study, in vitro produced nodal explants were found to be the best explants for maximum direct multiple shoot formation and elongation of shoots. These results were in accordance with the findings on in vitro shoot formation in Phyllanthus urinaria ${ }^{14,25}$ and Phyllanthus amarus ${ }^{24}$. However, the shoot regeneration percentage was affected by the type and concentrations of Plant Growth Regulators (PGRs). The shoot proliferation percent increased with elevated concentrations of BAP. On medium, incorporation of $1 \mathrm{mg} / \mathrm{l}$ of BAP alone, maximum number of explants responded for shoot regeneration $(97.36 \pm 0.46 \%)$ and produced maximum average number of shoots per explants $(7.8 \pm 0.15)$ (Fig. 1a). Comparatively, the shoot multiplication frequency was relatively low on MS medium containing Kin or TDZ (Table 1). The gradual decline in shoot formation response and increase in callus formation was found at higher concentrations of BAP, Kin and TDZ. The results of the current study confirm that, the cytokinin BAP was supe- 

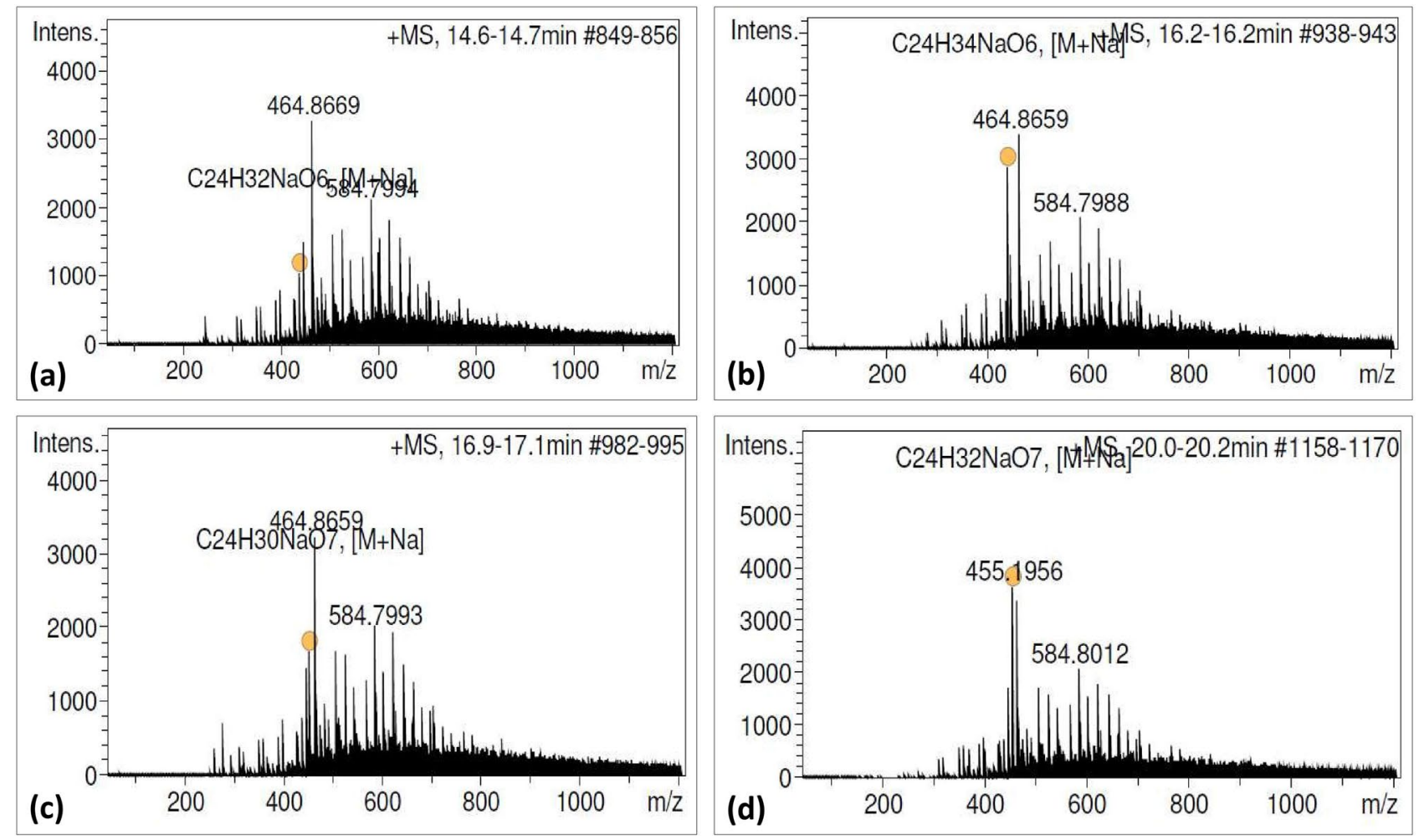

Figure 3. Product mass spectra of four lignans detected in P. tenellus by QTOF-MS in positive ion mode: (a) Phyltetralin (m/z 439.2007), (b) Phyllanthin (m/z 441.2173), (c) Hypophyllanthin (m/z 453.1806) and (d) Niranthin (m/z 455.1956).

rior for induction of multiple shoot regeneration in nodal explants of Phyllanthus species such as $P$. urinaria ${ }^{25}$, P. niruri ${ }^{26}$, P. amarus $^{27}$, P. maderaspatensis ${ }^{28}$ and $P$. fraternus $^{29}$. However, contrasting results are also reported in Phyllanthus amarus ${ }^{19,30}$ and Phyllanthus urinaria ${ }^{14}$; where the efficiency of shoot proliferation on Kin and TDZ was superior to BAP.

The response of shoot regeneration in nodal explants declined on incorporation of auxins together with BAP. Similar results were recorded in $P$. caroliniensis ${ }^{12}, P$. fraternus $^{31}$ and in $P$. reticulatus ${ }^{32}$. It is understood that the inclusion of auxins counteracts the effect of BAP for shoot formation. However, contrasting results were reported in $P$. tenellus ${ }^{15}$. It was suggested that only 3.5 shoots regeneration per nodal explants derived from seedlings was possible using optimized medium MS + Kin $(0.8 \mathrm{mg} / \mathrm{l})+$ Gibberellic acid $\left(\mathrm{GA}_{3}\right)(0.3 \mathrm{mg} / \mathrm{l})+\mathrm{IBA}(0.2 \mathrm{mg} / \mathrm{l})$. This difference might be possible due to differences in source of explants, the medium enriched with IAA, IBA, GA, and Kin and lacking the use of BAP. In the present study, on incorporation of cytokinins and auxins alone and combination, it was observed that BAP alone was best for maximum number of shoots regeneration per nodal explants $(7.8 \pm 0.15)$ (Table 1$)$. The variation in number of shoot formation might be attributed to the different cytokinins, their concentration, combination with other PGRs and source of explants.

In vitro rooting of shoots and acclimatization. Inadequate rooting is a major constraint to the survival rate of plantlets in field conditions and the success of in vitro regeneration protocol ${ }^{22}$. In vitro raised shoots (3-4 cm long) were removed from the culture vessel and inoculated individually on medium with various concentrations of auxins such as IAA, IBA, and NAA $(0.5,1,2$ and $3 \mathrm{mg} / \mathrm{l}$ of each). The root formation percentage from the shoots was varied with the type and concentration of auxins are shown in Supplementary Table 1. The root formation was observed from the cut end and nodal portion of the shoots within 14 days, which form an extensive well-developed root system after 21 days of culture. The maximum root formation (100\%) and number of roots per shoot were observed on medium containing 1-2 mg/l IAA (Fig. 1b, Supplementary Table 1). The incorporation of higher concentration of IAA $(3 \mathrm{mg} / \mathrm{l})$ or NAA or IBA $(2.0-3.0 \mathrm{mg} / \mathrm{l})$ induces callus intervening root formation. This difference in response may be attributed to the interaction of exogenous and endogenous levels of auxin in the medium and cultured shoots respectively as well as their uptake, transport and metabolism ${ }^{22}$. Similar observation was recorded in Phyllanthus amarus ${ }^{19}$ and Phyllanthus maderaspatensis ${ }^{28}$. On the contrary, the effectiveness of IBA over other auxins in rooting has been reported in $P$. urinaria ${ }^{25}, P$. frater$n u s^{29}$, P. reticulatus ${ }^{32}$ and in $P$. tenellus ${ }^{15}$.

The four-week-old well rooted plantlets $(8-10 \mathrm{~cm}$ in height) showed good growth on transfer to pots containing garden soil and sand (3:1) and placed in shade-net house (50\% light cut). After four weeks of hardening, all plantlets survived on transfer to field conditions. The plantlets produced normal flowers and fruits, phenotypically similar to the source plants (Fig. 1e). 


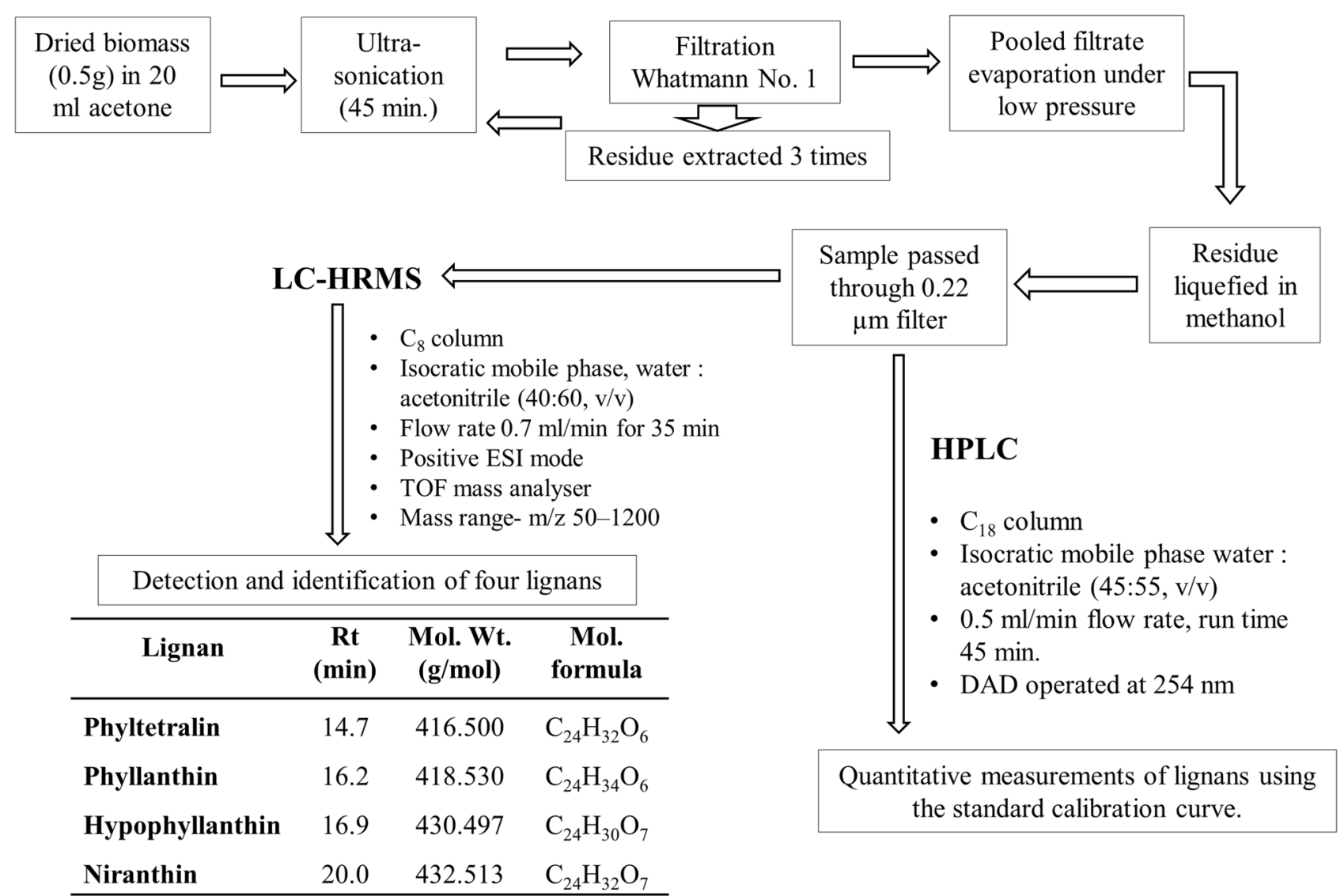

Figure 4. Schematic presentation of the developed protocol for detection and quantification of four lignans in naturally grown and in vitro raised biomass of Phyllanthus tenellus.

Callus induction and growth. Results of the experiments on callus induction and growth of callus are depicted in Table 2 and Supplementary Table 2. Among various permutations and combinations of PGRs, extensive callus formation was observed on medium containing 2-3 mg/l of individual auxins (2, 4-D, NAA, IAA, IBA) and cytokinins (BAP, Kin and TDZ). The induction of calluses from the cut ends was observed within two weeks of culture and by the end of the fourth week, the entire surface of explants was covered with callus. Texture and color of calluses varied with the type and concentration of growth regulators (Table 2, Supplementary Table 2). There was no significant difference observed on the growth of callus on incorporation of auxins together with cytokinins. Of the auxins and cytokinins tested, the best callus growth in terms of dry weight was recorded on 2, 4-D containing medium, next it was observed on NAA, IAA, IBA, TDZ, BAP, and Kin respectively. The callus on subculture to similar fresh medium at the interval of 28 days showed proliferation and growth over a period of 18 months. The callus produced on NAA, IAA, and IBA were compact, hard and whitish to gray-green in color. While on 2, 4-D, the callus was friable and slightly whitish to yellowish in color. The callus produced on Kin was whitish and compact while on BAP and TDZ, the callus was friable and greenish in color. Occasionally, rhizogenesis and shoot formation was observed in callus maintained on IAA or NAA and TDZ fortified medium respectively. However, no morphogenic response was observed on 2, 4-D incorporated media. Results of the current study revealed that 2, 4-D alone was superior to other PGRs for induction and proliferation of callus in both leaf and nodal explants of Phyllanthus tenellus Roxb. Similar effect of 2, 4-D on callus induction and proliferation was reported in Phyllanthus urinaria ${ }^{14}$, Phyllanthus tenellus ${ }^{15}$, Phyllanthus debilis ${ }^{33}$ and Phyllanthus reticulatus ${ }^{32}$.

Identification of bioactive lignans. The resultant chromatogram consisted of several peaks in acetone extract of naturally grown as well as in vitro raised biomass of $P$. tenellus. Out of which, the peaks appeared at 14.7, 16.2, 16.9 and $20.2 \mathrm{~min}$. and were detected and confirmed as phyltetralin, phyllanthin, hypophyllanthin and niranthin, respectively by comparing $R t$ and ESI mass spectra of available reference standards (Table 3, Figs. 2, 3, 4, Supplementary Fig. 1a, b). The peak appearing at $14.7 \mathrm{~min}$. of phyltetralin has molecular formula as $\mathrm{C}_{24} \mathrm{H}_{32} \mathrm{O}_{6}$ and molecular weight $(\mathrm{m} / \mathrm{z} 439.2002)$ was present with adduct ions $[\mathrm{M}+\mathrm{Na}]$. The chromatogram of standard reconfirmed the presence of phyltetralin at the same retention time as $14.7 \mathrm{~min}$. with the same molecular formula and molecular weight. Therefore, the compound was assigned as phyltetralin (Figs. 2a and 3a). The peak of phyllanthin was recorded at $16.2 \mathrm{~min}$. as molecular formula $\left(\mathrm{C}_{24} \mathrm{H}_{34} \mathrm{O}_{6}\right)$ and molecular weight $(\mathrm{m} / \mathrm{z}=441.2167)$ with adduct ions $[\mathrm{M}+\mathrm{Na}]$. The signal from standard phyllanthin fits in retention time and MS spectra. Therefore, the peak was confirmed as phyllanthin (Figs. $2 \mathrm{~b}$ and $3 \mathrm{~b}$ ). The peak of standard hypophyllanthin appeared at Rt $17.0 \mathrm{~min}$. and the mass spectra showed the characteristic adduct ion at $\mathrm{m} / \mathrm{z} 453.1798[\mathrm{M}+\mathrm{Na}]$. In plant 


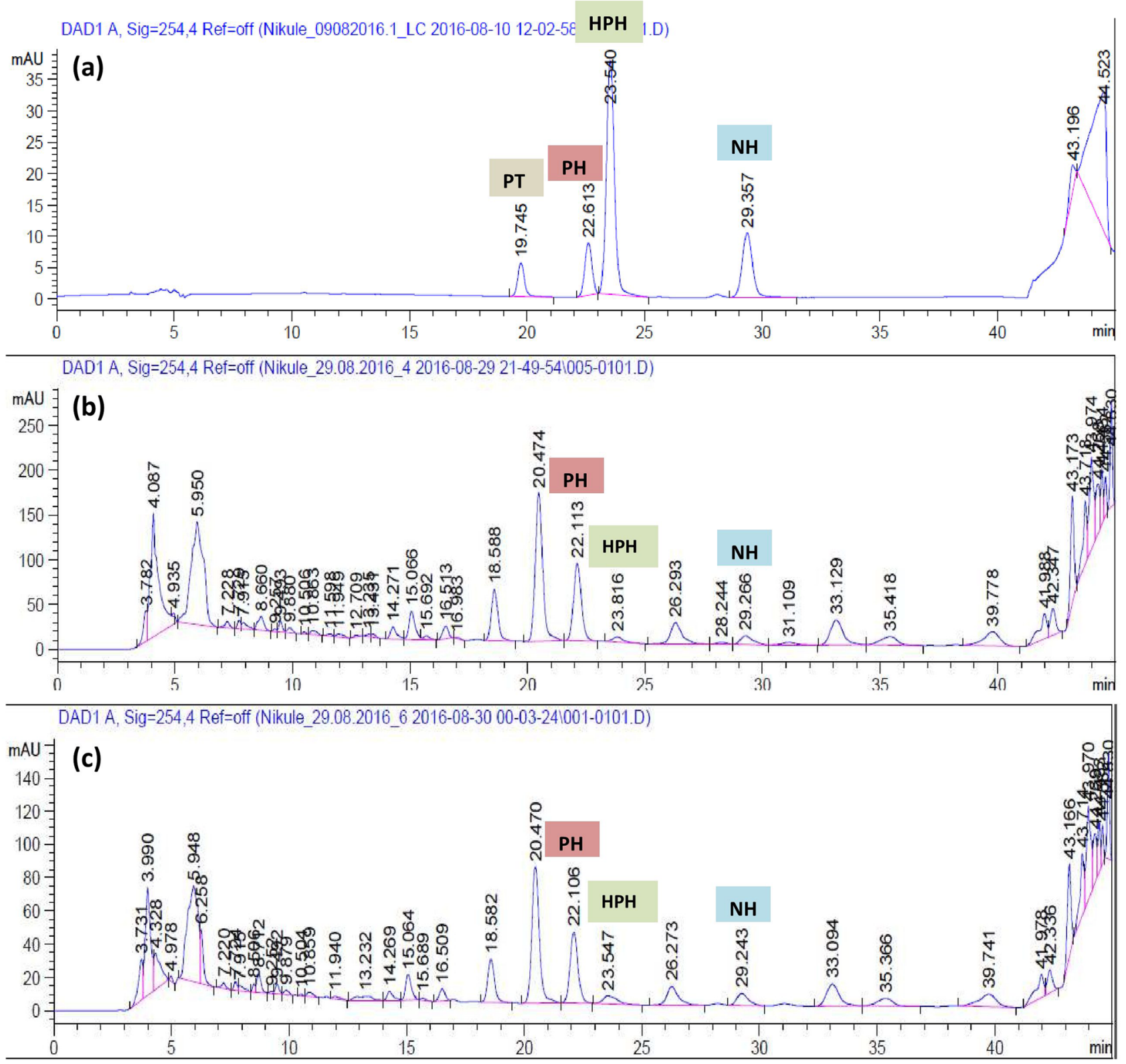

Figure 5. HPLC chromatograms for detection and quantification of lignans from in vitro grown plants in comparison with naturally grown plant of P. tenellus: (a) Chromatogram for standard peaks, (b) Chromatogram for naturally grown plant, and (c) Chromatogram for callus from in vitro grown plant.

extract also, corresponding mass spectra were observed with adduct ion $[\mathrm{M}+\mathrm{Na}] \mathrm{m} / \mathrm{z}$ at 453.1811 and molecular formula $\left(\mathrm{C}_{24} \mathrm{H}_{30} \mathrm{O}_{7}\right)$ were recorded which appeared at retention time $16.9 \mathrm{~min}$. (Figs. 2c and 3c). Niranthin appeared at Rt 20.0 min. with calculated molecular mass m/z 455.1953 and molecular formula $\left(\mathrm{C}_{24} \mathrm{H}_{32} \mathrm{O}_{7}\right)$ with adduct ion $[\mathrm{M}+\mathrm{Na}]$. Similar mass spectra were observed at retention time $20.2 \mathrm{~min}$. in the chromatogram of plant extract. Therefore, the peak was identified as niranthin (Figs. $2 \mathrm{~d}$ and $3 \mathrm{~d}$ ).

In the present investigation, total four lignans were identified in acetone extract of $P$. tenellus by using LCHRMS. Similarly, using UPLC-ESI-MS/MS, fifty-two compounds including phyllanthin and hypophyllanthin were characterized in ethanol extract of $P$. amarus $^{34}$. Using the same technique, there was no report on niranthin and phyltetralin. However, identification and characterization of only quercetin, ellagic acid, kaempferol and their derivatives was carried out in ethanol extract of P. emblica, P. fraternus, P. amarus and P. niruri ${ }^{35}$. The lignans phyllanthin, hypophyllanthin, niranthin and ellagic acid were identified by using LC-MS in methanol extract of $P$. amarus and P. urinaria ${ }^{36}$. Twenty phenolic compounds were recorded in UPLC-ESI-MS analysis but phyllanthin, hypophyllanthin, niranthin and phyltetralin were not recorded in methanol extract of $P$. acuminatus ${ }^{37}$. Using reversed phase HPLC technique, the lignans phyllanthin, hypophyllanthin, niranthin and phyltetralin were reported in $P$. amarus, $P$. maderaspatensis, $P$. urinaria, $P$. fraternus and $P$. virgatus ${ }^{38,39}$. However, only lignans niranthin, nirtetralin and hinokinin were reported in methanol extract of $P$. tenellus but not phyllanthin, 

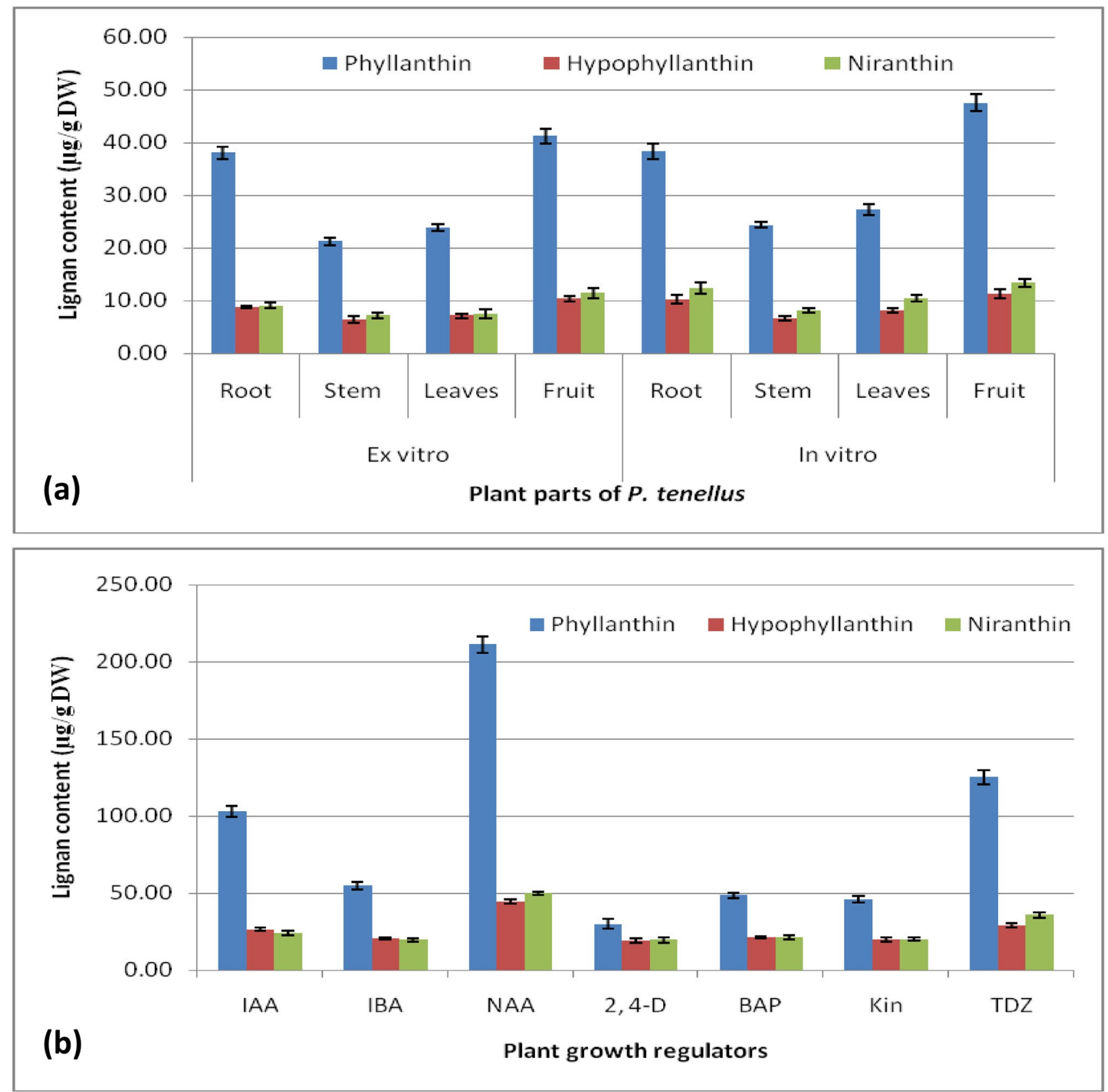

Figure 6. Lignan $(\mathrm{PH}, \mathrm{HPH}$ and $\mathrm{NH})$ content $(\mu \mathrm{g} / \mathrm{g} \mathrm{DW} \pm \mathrm{SE})$ in acetone extracts from biomass of $P$. tenellus: (a) Plant parts of in vitro and ex-vitro grown plants, and (b) Effect of auxins and cytokinins on accumulation of lignan in leaf derived callus. Data represents mean \pm standard error of three replicates.

hypophyllanthin, and phyltetralin ${ }^{7}$. To the best of our knowledge, the current study is the first report for the detection and quantification of phyllanthin, hypophyllanthin, and phyltetralin in acetone extract of $P$. tenellus. The difference in detection might be due to different solvents used for extraction and separation and detection capacity of the systems used.

Effect of PGRs on lignans accumulation. Plant growth regulators play a significant role in biosynthesis of secondary metabolites in plants ${ }^{40}$. In the present investigation, HPLC was used to quantitative determination of lignans (Fig. 5). The obtained data showed that the lignans content was variable in Phyllanthus tenellus in vitro raised plantlets, field-grown plants and in callus grown on media containing different auxins (IAA, IBA, 2, 4-D, NAA) and cytokinins (TDZ, BAP, and Kin). The content of $\mathrm{PH}, \mathrm{HPH}$ and NH were slightly higher in different organs of in vitro raised plantlets compared to the organs of ex-vitro grown plants (Fig. 6a, Supplementary Table 3). However, compared to field and in vitro grown plant parts, the content of lignan $\mathrm{PH}, \mathrm{HPH}$ and $\mathrm{NH}$ was about double to triple times higher in leaf derived callus grown on different media. The content was higher in callus obtained on NAA; followed by TDZ and IAA respectively, whereas the content was low in callus produced 
on MS incorporated with IBA, BAP, and Kin (Fig. 6b, Supplementary Table 4). Similarly, in earlier reports, the inclusion of NAA in the medium was effective for accumulation of PH and HPH in callus of P. amarus ${ }^{19}$ and P. urinaria ${ }^{41}$ and in other plant species such as berberin in cell culture of Thalictrum minus ${ }^{42}$, catharanthine in cell culture of Catharanthus roseus ${ }^{43}$ and rutin in root cultures of Fagopyrum esculentum ${ }^{44}$. In the present study, among auxins and cytokinins used, the content of lignans was low in callus grown on medium incorporated with 2, 4-D. Similar results were reported in P. amarus $^{19,45}$.

In previous studies, variable quantity of lignans $\mathrm{PH}$ and $\mathrm{HPH}$ were reported in $P$. amarus and different species of Phyllanthus ${ }^{46-49}$ (Supplementary Table 5). The maximum content of lignans PH and HPH was observed in P. amarus followed by P. niruri and next it was recorded in the current study in P. tenellus. PT and NH were quantified only in P. amarus and P.niruri. Therefore, the results of the present study have revealed that $P$. tenellus can be one of the best sources of bioactive lignans $\mathrm{PH}, \mathrm{HPH}$ and NH. The differences in metabolite content in source material may be due to the influence of various factors like ecological conditions, age of the plant parts, drying methods, extraction methods, extraction solvents, and type of analytical techniques used.

\section{Conclusion}

The present investigations are the first report on detection and quantification of bioactive lignans phyllanthin, hypophyllanthin, niranthin and phyltetralin in Phyllanthus tenellus. The herb may emerge as one of the best source of bioactive lignans. The in vitro propagation protocol would be useful for the application of biotechnological approaches for improvement in phyto-pharming. This study revealed that lignan compounds accumulation was influenced by the in vivo and in vitro conditions, type of auxins and cytokinins and their concentration in the nutrient medium. The content of lignans in callus culture can be significantly augmented by the presence of NAA in the nutrient medium. Further, these techniques can be used to scale up the process of lignan production at industrial level round the year. The results tend to support the use of Phyllanthus tenellus in country wise developed traditional medicinal systems to cure diseases and disorders.

Received: 5 November 2019; Accepted: 1 June 2020

Published online: 30 June 2020

\section{References}

1. Silva, T. C. D. L. et al. Acute toxicity study of stone-breaker (Phyllanthus tenellus Roxb.) Rev. Cienc Farm Basica Aplicada. 33, 205-210 (2012).

2. Santos, A. R. et al. Analgesic effects of callus culture extracts from selected species of Phyllanthus in mice. J. Pharm. Pharmacol. 46, 755-759 (1994).

3. Oliveira, D. F. et al. Antibacterial activity of plant extracts from Brazilian southeast region. Fitoterapia 78, 142-145 (2007).

4. Calixto, J. B., Santos, A. R. S., Paulino, N., Cechinel, V. \& Yunes, R. A. The plants of the genus Phyllanthus as a potential source of new drugs. Ciênc cult (Säo Paulo). 49, 422-432 (1997).

5. Santiago, L. J. M., Louro, R. P. \& De Oliveira, D. E. Compartmentation of phenolic compounds and phenylalanine ammonia-lyase in leaves of Phyllanthus tenellus Roxb. and their induction by copper sulphate. Ann Bot. 86, 1023-1032 (2000).

6. Huang, Y. L., Chen, C. C., Hsu, F. E. \& Chen, C. F. Two tannins from Phyllanthus tenellus. J. Nat. Prod. 61, 523-524 (1998).

7. Huang, R. L. et al. Screening of 25 compounds isolated from Phyllanthus species for anti-human hepatitis B virus in vitro. Phytother. Res. 17, 449-453 (2003).

8. Wei, W., Li, X., Wang, K., Zheng, Z. \& Zhou, M. Lignans with Anti-Hepatitis B virus activities from Phyllanthus niruri L. Phytother. Res. 26, 964-968 (2012).

9. Elendran, S., Wang, L. W., Prankerd, R. \& Palanisamy, U. D. The physicochemical properties of geraniin, a potential antihyperglycemic agent. Pharm. Biol. 53, 1719-1726 (2015).

10. Azam, M. \& Ajitha, M. Phyllanthin: a potential lead molecule for the future needs. Int. J. Pharm. Phytochem. Res. 9, 1081-1089. https://doi.org/10.25258/phyto.v9i08.9615 (2017).

11. Nisar, M. et al. Chemical components and biological activities of the Genus Phyllanthus: a review of the recent literature. Molecules 23, 2567. https://doi.org/10.3390/molecules23102567 (2018).

12. Catapan, E., Otuki, M. F. \& Viana, A. M. In vitro culture of Phyllanthus caroliniensis (Euphorbiaceae). Plant Cell Tissue Organ Cult. 62, 195-202 (2000).

13. Catapan, E., Otuki, M. F. \& Viana, A. In vitro culture of Phyllanthus stipulatus (Euphorbiaceae). Braz. J. Bot. 24, 25-34 (2001).

14. Catapan, E., Luis, M., Da Silva, B., Moreno, F. N. \& Viana, A. M. Micropropagation, callus and root culture of Phyllanthus urinaria (Euphorbiaceae). Plant Cell Tissue Organ Cult. 70, 301-309 (2002).

15. Victorio, C. P., Henriques, A. B., Tavares, E. S., Esquibel, M. A. \& Lage, C. L. S. Standardized production of Phyllanthus tenellus Roxb. by plant tissue culture. Rev. Cienc. Agron. 41, 272-278 (2010).

16. Bapat, V. A., Yadav, S. R. \& Dixit, G. B. Rescue of endangered plants through biotechnological applications. Natl. Acad. Sci. Lett. 31, 201-210 (2008).

17. Baskaran, P., Kumari, A., Naidoo, D. \& Van Staden, J. In vitro propagation and biochemical changes in Aloe pruinosa. Ind. Crops Prod. 77, 51-58 (2015).

18. Murashige, T. \& Skoog, F. A revised medium for rapid growth and bioassays with tobacco tissue cultures. Physiol. Plant 15, 473-497 (1962).

19. Nitnaware, K. M., Naik, D. G. \& Nikam, T. D. Thidiazuron-induced shoot organogenesis and production of hepatoprotective lignan phyllanthin and hypophyllanthin in Phyllanthus amarus. Plant Cell Tissue Organ Cult. 104, 101-110 (2011).

20. Murugaiyah, V. \& Chan, K. L. Determination of four lignans in Phyllanthus niruri L. by a simple high-performance liquid chromatography method with fluorescence detection. J. Chromatogr. A. 1154, 198-204 (2007).

21. Jiang, Q. et al. Establishment of an in vitro plant regeneration protocol for Casuarina cunninghamiana Miq. via indirect organogenesis. New For. 43, 143-154 (2012).

22. Mali, A. M. \& Chavan, N. S. In vitro rapid regeneration through direct organogenesis and ex-vitro establishment of Cucumis trigonus Roxb.: an underutilized pharmaceutically important cucurbit. Ind. Crops Prod. 83, 48-54 (2016).

23. Patel, A. K., Agarwal, T., Phulwaria, M., Kataria, V. \& Shekhawat, N. S. An efficient in vitro plant regeneration system from leaf of mature plant of Leptadenia reticulata (Jeewanti): a life giving endangered woody climber. Ind. Crops Prod. 52, 499-505 (2014).

24. Raja, H. D. Micropropagation of Phyllanthus amarus from nodal explant. World J. Pharm. Pharm. Sci. 4, 1153-1157 (2015). 
25. Kalidass, C. \& Mohan, V. R. In vitro rapid clonal propagation of Phyllanthus urinaria Linn. (Euphorbiaceae): a medicinal plant. Researcher 4, 61-65 (2009).

26. Liang, O. P. \& Keng, C. L. In vitro plant regeneration, flowering and fruiting of Phyllanthus niruri L. (Euphorbiaceae). Int. J. Bot. 2, 409-414 (2006).

27. Xavier, J. R., Gnanam, R., Murugan, M. P. \& Pappachan, A. Clonal propagation of Phyllanthus amarus: a hepatoprotector. Pharmacogn. Mag. 8, 78-82 (2012).

28. Raja, A., Blessy, J. A., Sathiya, R. \& Jayabalan, N. In vitro regeneration of Phyllanthus maderaspatensis L.: a traditional medicinal plant. Indian J. Nat. Sci. 1, 217-224 (2011).

29. Upadhyay, R., Tiwari, K. N. \& Singh, K. High frequency shoots regeneration for mass multiplication of Phyllanthus fraternus Webster-an important antiviral and hepatoprotective Plant. Appl. Biochem. Biotechnol. 169, 2303-2314 (2013).

30. Bhattacharya, R. \& Bhattacharya, S. High frequency in vitro propagation of Phyllanthus amarus Schum. \& Thom. by shoot tip culture. Indian J. Exp. Biol. 39, 1184-1187 (2001).

31. Hassan, A. S. \& Khatun, R. In vitro shoot proliferation and plant regeneration of Phyllanthus fraternus Webster (B. Bhuiamla), a seasonal medicinal herb. Bangladesh J. Sci. Ind. Res. 46, 205-210 (2011).

32. Shiragave, P. D. In vitro micropropagation study in a medicinal plant Phyllanthus reticulates Poir. Int. J. Adv. Life Sci. 8, 161-166 (2015).

33. Malayaman, V., Ghouse, B. M. \& Kolar, A. B. An efficient callus induction from Phyllanthus debilis Klein Ex Willd: a wild medicinal plant of Eastern Ghats, India. Int. J. Pure Appl. Biosci. 2, 181-186 (2014).

34. Kumar, S. et al. Rapid qualitative and quantitative analysis of bioactive compounds from Phyllanthus amarus using LC/MS/MS techniques. Ind. Crops Prod. 69, 143-152 (2015).

35. Kumar, S., Singh, A. \& Kumar, B. Identification and characterization of phenolics and terpenoids from ethanolic extracts of Phyllanthus species by HPLC-ESI-QTOF-MS/MS. J. Pharm. Anal. 7, 214-222 (2017).

36. Muthusamy, A. et al. Quantitative analysis of Phyllanthus species for bioactive molecules using high-pressure liquid chromatography and liquid chromatography-mass spectrometry. Proc. Natl. Acad. Sci. India 88, 1043-1054 (2018).

37. Navarro, M. et al. Flavonoids and ellagitannins characterization, antioxidant and cytotoxic activities of Phyllanthus acuminatus Vahl. Plants. 6, 62. https://doi.org/10.3390/plants6040062 (2017).

38. Sarin, B., Verma, N., Martín, J. P. \& Mohanty, A. An overview of important ethnomedicinal herbs of Phyllanthus species: present status and future prospects. Sci. World J. https://doi.org/10.1155/2014/839172 (2014).

39. Shanker, K. et al. Simultaneous analysis of six bioactive lignans in Phyllanthus species by reversed phase hyphenated high performance liquid chromatographic technique. Acta Chromatogr. 23, 321-337 (2011).

40. Jamwal, K., Bhattacharya, S. \& Puri, S. Plant growth regulator mediated consequences of secondary metabolites in medicinal plants. J. Appl. Res. Med.. Aromat. Plants. 9, 26-38 (2018).

41. Muthusamy, A., Prasad, H. N. N., Sanjay, E. R., Rao, M. R. \& Satyamoorthy, K. Impact of precursors and plant growth regulators on in vitro growth, bioactive lignans, and antioxidant content of Phyllanthus species. In Vitro Cell Dev. Biol. Plant. 52, 598-607 (2016).

42. Nakagawa, K., Fukui, H. \& Tabata, M. Hormonal regulation of berberine production in cell suspension cultures of Thalictrum minus. Plant Cell Rep. 5, 69-71 (1986).

43. Zhao, J., Hu, Q., Guo, Q. \& Zhu, W. H. Effects of stress factors, bioregulators, and synthetic precursor on indole alkaloid production in compact callus clusters cultures of Catharanthus roseus. Appl. Microbial Biotechnol. 55, 693-698 (2001).

44. Lee, S. Y. et al. Growth and rutin production in hairy root cultures of buckwheat (Fagopyrum esculentum M.). Prep. Biochem. Biotechnol. 37, 239-246 (2007).

45. Ramawat, K., Merrilion, J. Biotechnology-secondary metabolites. Mohan Primlani for Oxford and IBH Delhi. $243-247$ (1999).

46. Banerjee, A. \& Chattopadhyay, S. Effect of over-expression of Linum usitatissimum Pinoresinol Lariciresinol Reductase (LuPLR) gene in transgenic Phyllanthus amarus. Plant Cell Tissue Organ Cult. 103, 315-323 (2010).

47. Tripathi, A. K., Verma, R. K., Gupta, A. K., Gupta, M. M. \& Khanuja, S. P. Quantitative determination of phyllanthin and hypophyllanthin in Phyllanthus species by high-performance thin layer chromatography. Phytochem. Anal. 17, 394-397 (2006).

48. Duy, P. M., Hien, N. N., Nhung, H. N., Sanh, N. D. \& Quynh, N. T. Growth promotion and secondary metabolite accumulation of Phyllanthus amarus cultured photoautotrophically under carbon dioxide enriched condition. Tap Chi Sinh Hoc. 34, 249-256 (2012)

49. Thakur, J. S., Agarwal, R. K. \& Kharya, M. D. Enhancing hepatoprotective bioactives of Phyllanthus amarus through immobilization by growth promoters and media changes. Indian J. Pharm. Sci. 73, 271-275 (2011).

\section{Acknowledgements}

Authors wish to acknowledge the support of the Department of Botany and Central Instrumentation Facility, Savitribai Phule Pune University for providing tissue culture, analytical and LC-HRMS facility.

\section{Author contributions}

TDN and KMN designed and guided the experiments. HAN, MRC and NSK performed the experiments (establishment of in vitro shoot cultures, rooting of shoots, callus cultures, HPLC, LC-HRMS and data analysis), MYB participated in various stages of the experiments. All authors were involved in the preparation of manuscript.

\section{Competing interests}

The authors declare no competing interests.

\section{Additional information}

Supplementary information is available for this paper at https://doi.org/10.1038/s41598-020-67637-8.

Correspondence and requests for materials should be addressed to T.D.N.

Reprints and permissions information is available at www.nature.com/reprints.

Publisher's note Springer Nature remains neutral with regard to jurisdictional claims in published maps and institutional affiliations. 
(c) (i) Open Access This article is licensed under a Creative Commons Attribution 4.0 International cc) License, which permits use, sharing, adaptation, distribution and reproduction in any medium or format, as long as you give appropriate credit to the original author(s) and the source, provide a link to the Creative Commons license, and indicate if changes were made. The images or other third party material in this article are included in the article's Creative Commons license, unless indicated otherwise in a credit line to the material. If material is not included in the article's Creative Commons license and your intended use is not permitted by statutory regulation or exceeds the permitted use, you will need to obtain permission directly from the copyright holder. To view a copy of this license, visit http://creativecommons.org/licenses/by/4.0/.

(C) The Author(s) 2020 